Abstracta Iranica

Revue bibliographique pour le domaine irano-aryen

Volume 28 | 2007

Comptes rendus des publications de 2005

\title{
«Iran: The Status Quo Power ». Current History, janvier 2005, pp. 30-36.
}

\section{Anicée Van Engeland}

\section{(2) OpenEdition}

1 Journals

\section{Édition électronique}

URL : http://journals.openedition.org/abstractairanica/19271

DOI : 10.4000/abstractairanica.19271

ISSN : 1961-960X

Éditeur :

CNRS (UMR 7528 Mondes iraniens et indiens), Éditions de l'IFRI

\section{Édition imprimée}

Date de publication : 15 mai 2007

ISSN : 0240-8910

\section{Référence électronique}

Anicée Van Engeland, « «Iran: The Status Quo Power ». Current History, janvier 2005, pp. 30-36. », Abstracta Iranica [En ligne], Volume 28 | 2007, document 432, mis en ligne le 18 septembre 2007, consulté le 25 septembre 2020. URL : http://journals.openedition.org/abstractairanica/19271 ; DOI : https://doi.org/10.4000/abstractairanica.19271

Ce document a été généré automatiquement le 25 septembre 2020.

Tous droits réservés 


\title{
«Iran: The Status Quo Power ». Current History, janvier 2005, pp. 30-36.
}

\author{
Anicée Van Engeland
}

1 L'Iran est aujourd'hui face à beaucoup de défis mais dispose aussi de beaucoup d'opportunités et d'ouvertures. Jamais la situation n'a été plus paradoxale, souligne l'auteur. L'avenir de l'Iran est aujourd'hui entre les mains d'un mouvement populaire, la société civile, qui lutte contre un gouvernement populiste. De plus, la chute de Saddam Hussein a ouvert à l'Iran de nouvelles possibilités d'étendre son influence en Irak tout en, paradoxalement, augmentant le risque d'une invasion américaine. Il en va de même pour l'Afghanistan : la menace talibane a disparu, donnant ainsi la possibilité à l'Iran d'étendre son influence en Afghanistan; mais parallèlement le pays n'a jamais eu de frontières aussi fragilisées et perméables à une éventuelle invasion américaine. Les paradoxes traversent et caractérisent donc aussi la situation géostratégique iranienne et la situation intérieure.

INDEX

Thèmes : 13.1. Iran 
AUTEURS

ANICÉE VAN ENGELAND

Paris 